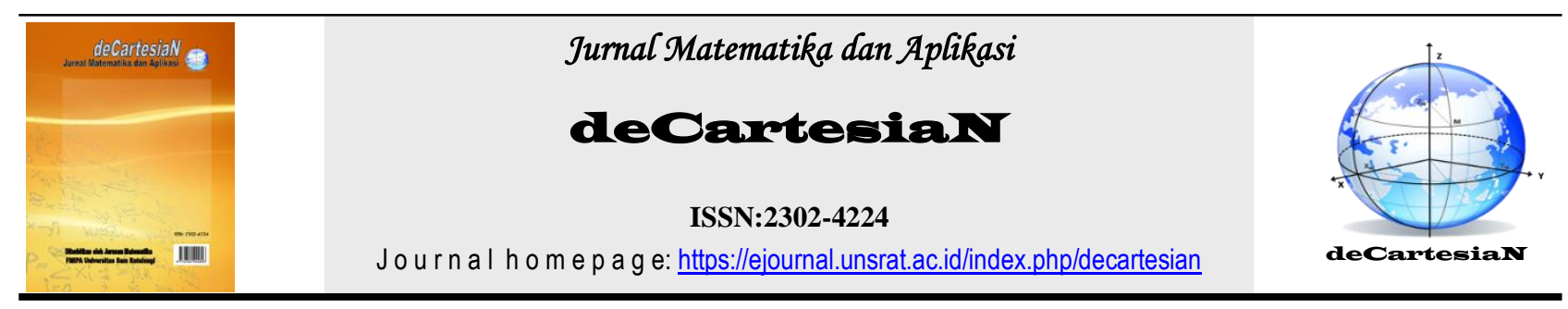

\title{
Prediksi Jumlah Produksi Mebel Pada CV. Sinar Sukses Manado Menggunakan Fuzzy Inference System
}

\author{
Try Buana Donda ${ }^{1}$, Chriestie E. J. C. Montolalu ${ }^{1}$, Altien J. Rindengan ${ }^{1 *}$ \\ 1Program Studi Matematika-Fakultas Matematika dan Ilmu Pengetahuan Alam Universitas Sam Ratulangi Manado, Indonesia \\ *Corresponding author : altien@unsrat.ac.id
}

\begin{abstract}
A B S T R A K
Industri mebel di Indonesia sangat berpotensi untuk tumbuh dan berkembang. Hal inilah yang membuat banyak bermunculan para pelaku industri mebel di tiap-tiap daerah hingga terjadi persaingan mulai dari kualitas sampai banyaknya jumlah mebel yang diproduksi. Penelitian ini bertujuan untuk membuat sebuah Sistem Pendukung Keputusan (SPK) dan menerapkan Fuzzy Inference System untuk melakukan prediksi produksi mebel. Mamdani merupakan metode yang digunakan untuk melakukan inferensi sistem yang didasarkan pada data persediaan dan permintaan mebel. Data yang digunakan adalah 60 data sekunder yang diperoleh dari CV. Sinar Sukses. Dalam melakukan pengujian sistem aplikasi digunakan uji-t sampel berpasangan. Fuzzy Inference System metode Mamdani dapat digunakan untuk melakukan prediksi jumlah mebel dilihat dari keseluruhan data yang diuji menunjukkan sebagian besar selisih antara jumlah prediksi produksi menggunakan sistem aplikasi dengan produksi sebenarnya lebih kecil dibandingkan dengan selisih antara jumlah produksi perusahaan dengan produksi sebenarnya. Standard error dari masing-masing barang yaitu untuk pintu : standard error prediksi produksi pintu $=0,534$ lebih kecil dari standard error produksi pintu $=0,634$ dan untuk lemari : standard error prediksi produksi lemari $=0,458$ lebih kecil dari standard error produksi lemari $=0,735$.
\end{abstract}

\author{
INFO ARTIKEL \\ Diterima : 19 Maret 2018 \\ Diterima setelah revisi : 26 Maret 2018 \\ Tersedia online $\quad: 12$ April 2018
}

\section{Kata Kunci:}

Produksi mebel,

Fuzzy Inference System,

Metode Mamdani,

Sistem Pendukung Keputusan

\section{PENDAHULUAN}

Industri mebel di Indonesia sangat berpotensi untuk tumbuh dan berkembang karena didukung oleh pengrajin yang terampil dan juga sumber bahan baku yang melimpah. Hal inilah yang membuat banyak bermunculan para pelaku industri mebel di tiap-tiap daerah hingga terjadi persaingan mulai dari kualitas sampai banyaknya jumlah mebel yang diproduksi oleh satu perusahaan untuk mendapatkan keuntungan yang maksimal.

Keuntungan yang maksimal diperoleh dari penjualan yang maksimal. Penjualan yang maksimal artinya dapat memenuhi permintaan-permintaan yang ada. Oleh karena itu perencanaan ataupun prediksi jumlah produk kedepannya dalam suatu perusahaan sangatlah penting agar dapat memenuhi permintaan pasar dengan tepat dan dengan jumlah yang sesuai. Faktor-faktor yang perlu diperhatikan dalam menentukan jumlah produk, antara lain: sisa persediaan satu periode sebelumnya dan perkiraan jumlah permintaan satu periode selanjutnya [1].

Salah satu cara untuk memprediksi jumlah produksi menggunakan data persediaan dan permintaan pada perusahaan mebel yaitu menggunakan logika fuzzy. Logika fuzzy merupakan suatu cara untuk memetakan ruang input ke dalam suatu ruang output. Teknik ini menggunakan teori matematis himpunan fuzzy. Logika fuzzy berhubungan dengan ketidakpastian yang telah menjadi sifat alamiah manusia [2].

Beberapa penelitian sebelumnya yaitu menentukan jumlah produksi dengan logika fuzzy menggunakan metode Tsukamoto [3] dan menentukan perencanaan produksi menggunakan model fuzzy goal programming pada CV. Sinar Sukses [4][5].

Berdasarkan uraian di atas, maka dalam penelitian ini dengan menggunakan logika fuzzy akan dilakukan prediksi jumlah produksi mebel berdasarkan 
data persediaan dan jumlah permintaan pada perusahaan CV. Sinar Sukses di Kota Manado. Penelitian ini akan menggunakan bantuan komputer untuk membangun sistem pendukung keputusannya dan metode yang akan digunakan yakni metode Fuzzy Inference System Mamdani.

\section{MANAJEMEN PRODUKSI}

Istilah produksi dan operasi sering dipergunakan dalam suatu organisasi yang menghasilkan keluaran atau output baik berupa barang dan jasa, pengertian produksi dalam arti luas sebagai kegiatan yang mentransformasikan masukan (input) menjadi keluaran (output), tercakup semua kegiatan yang menghasilkan barang atau jasa serta kegiatan lain yang mendukung usaha untuk menghasilkan produk tersebut [6].

\section{Logika Fuzzy}

Logika fuzzy merupakan peningkatan dari logika Boolean. Dalam logika Boolean menyatakan bahwa segala sesuatu hanya dapat diekspresikan dalam dua nilai yaitu o dan 1, hitam dan putih, ya atau tidak. Dalam logika fuzzy memungkinkan nilai keanggotaan antara o dan 1, sehingga dalam logika fuzzy mengenal istilah hitam, keabuan, dan putih atau sedikit, lumayan dan sangat [7].

\subsection{Fungsi Keanggotaan}

Fungsi keanggotaan (membership function) adalah suatu kurva yang menunjukkan pemetaan titiktitik input data kedalam nilai keanggotaanya (derajat keanggotaan) yang memiliki interval antara o sampai 1 . Salah satu cara yang dapat digunakan untuk mendapatkan nilai keanggotaan adalah dengan melalui pendekatan fungsi [8].

Ada beberapa fungsi keanggotaan yang bisa digunakan [8] sebagai berikut :

- Representasi Linear

Pada representasi linear, pemetaan input ke derajat keanggotaanya digambarkan sebagai suatu garis lurus. Terdapat dua keadaan himpunan fuzzy yang linear.

Pertama, kenaikan himpunan dimulai pada nilai domain yang memiliki derajat keanggotaan nol (o) bergerak ke kanan menuju ke nilai domain yang memiliki derajat keanggotaan yang lebih tinggi seperti pada Gambar 1.

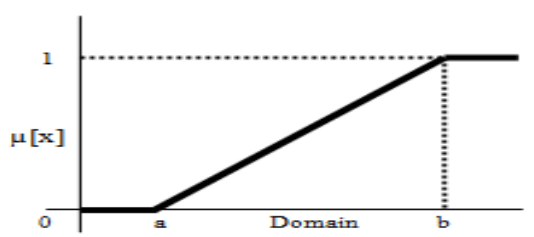

Gambar 1. Representasi Linear Naik

Persamaan Fungsi Keanggotaan :

$\mu[x]=\left\{\begin{array}{cl}0 ; & x \leq a \\ (x-a) /(b-a) ; & a<x<b \\ 1 ; & x \geq b\end{array}\right.$

Keterangan :

$\mu[x]=$ nilai keanggotaan suatu item $\mathrm{x}$

Kedua, merupakan kebalikan yang pertama. Garis lurus dimulai dari nilai domain dengan derajat keanggotaan tertinggi pada sisi kiri, kemudian bergerak menurun ke nilai domain yang memiliki derajat keanggotaan lebih rendah seperti pada Gambar 2.

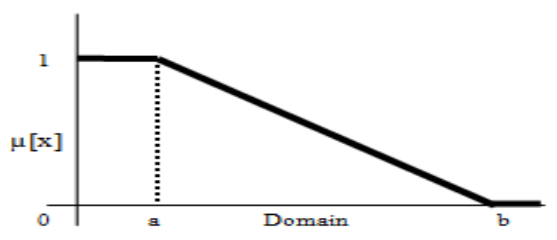

Gambar 2. Representasi Linear Turun

Persamaan Fungsi Keanggotaan :

$$
\mu[x]=\left\{\begin{array}{cl}
1 ; & x \leq a \\
(b-x) /(b-a) ; & a<x<b \\
0 ; & x \geq b
\end{array}\right.
$$

Keterangan :

$\mu[x]=$ nilai keanggotaan suatu item $x$

- Representasi kurva segitiga.

Representasi kurva segitiga merupakan gabungan antara dua garis linear. Representasi kurva segitiga dapat dilihat pada gambar 3 .

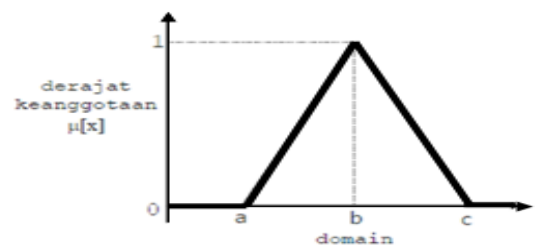

Gambar 3. Representasi Kurva Segitiga

Persamaan Fungsi Keanggotaan :

$$
\mu(x)=\left\{\begin{array}{ccl}
0 & ; x \leq \mathrm{a} \text { atau } \mathrm{x} \geq \mathrm{c} \\
& \frac{\mathrm{x}-\mathrm{a}}{\mathrm{b}-\mathrm{a}} & ; \mathrm{a}<x<b \\
& 1 \mathrm{c}-\mathrm{x}=b \\
\frac{\mathrm{c}-\mathrm{x}}{\mathrm{c}-\mathrm{b}} & ; b<x<c
\end{array}\right.
$$

Keterangan :

$\mu[x]=$ nilai keanggotaan suatu item $\mathbf{x}$

\section{- Kurva trapesium.}

Memiliki bentuk dasar seperti kurva segitiga, namun terdapat beberapa titik yang memiliki nilai keanggotaan sama dengan satu. Representasi kurva trapesium dapat dilihat pada gambar 4 .

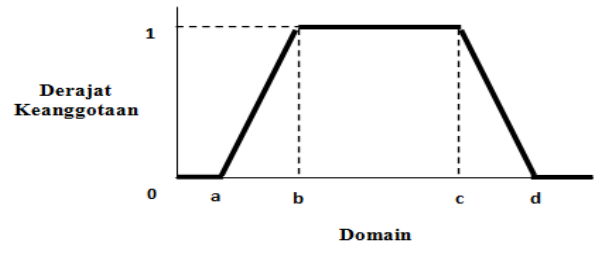

Gambar 4. Representasi Kurva Trapesium

Persamaan fungsi keanggotaann :

$$
\mu(x)=\left\{\begin{array}{ccl}
0 & ; x \leq \mathrm{a} \text { atau } \mathrm{x} \geq \mathrm{c} \\
& \frac{\mathrm{x}-\mathrm{a}}{\mathrm{b}-\mathrm{a}} & ; \mathrm{a}<x<b \\
1 & ; b \leq x \leq c \\
\frac{d-x}{d-c} & ; c<x<d
\end{array}\right.
$$

Keterangan :

$\mu[x]=$ nilai keanggotaan suatu item $\mathrm{x}$.

\subsection{Fuzzy Inference System Metode Mamdani}

Metode mamdani sering dikenal sebagai metode Max-Min. Metode ini diperkenalkan oleh Ebrahim Mamdani pada tahun 1975. Untuk mendapatkan output, diperlukan 4 tahapan [8] : 
1. Pembentukan himpunan fuzzy

Pada metode mamdani, baik variabel input maupun variabel output dibagi menjadi satu atau lebih himpunan fuzzy.

2. Aplikasi fungsi implikasi (aturan)

Pada metode mamdani, fungsi implikasi yang digunakan adalah min.

3. Komposisi aturan

Tidak seperti penalaran monoton, apabila system terdiri dari beberapa aturan, maka inferensi diperoleh dari kumpulan dan korelasi antar aturan. Ada 3 metode yang digunakan dalam melakukan inferensi system fuzzy, yaitu : $\max$, additive dan probabilistik OR (probor)

a. Metode Max (Maximum)

Pada metode ini, solusi himpunan fuzzy diperoleh dengan cara mengambil nilai maksimum aturan, kemudian menggunakannya untuk memodifikasi daerah fuzzy, dan mengaplikasikannya ke output dengan menggunakan operator OR (union). Jika semua proposisi telah dievaluassi, maka output akan berisi suatu himpunan fuzzy yang merefleksikan kontribusi dari tiap-tiap proposisi [8].

Secara umum dapat dituliskan :

dengan:

$$
\mu_{s f}\left[x_{i}\right]=\max \left(\mu_{s f}\left[x_{i}\right], \mu_{k f}\left[x_{i}\right]\right)
$$

$\mu_{s f}\left[x_{i}\right]=$ nilai keanggotaan solusi fuzzy sampai aturan ke-I;

$\mu_{k f}\left[x_{i}\right]=$ nilai keanggotaan konsekuen fuzzy aturan ke-i;

b. Metode Additive (Sum)

Pada metode ini, solusi himpunan fuzzy diperoleh dengan cara melakukan bounded-sum terhadap semua output daerah fuzzy [8]

dengan:

$$
\mu_{s f}\left[x_{i}\right]=\min \left(1, \mu_{s f}\left[x_{i}\right]+\mu_{k f}\left[x_{i}\right]\right)
$$

$\mu_{s f}\left[x_{i}\right]=$ nilai keanggotaan solusi fuzzy sampai aturan ke-I;

$\mu_{k f}\left[x_{i}\right]=$ nilai keanggotaan konsekuen Fuzzy aturan ke-I;

c. Metode Probabilistik OR (probor)

Pada metode ini, solusi himpunan fuzzy diperoleh dengan cara melakukan product terhadap semua output daerah fuzzy [8]. Secara umum dituliskan: $\mu_{s f}\left[x_{i}\right]=\left(\mu_{s f}\left[x_{i}\right]+\mu_{k f}\left[x_{i}\right]\right)-\left(\mu_{s f}\left[x_{i}\right] * \mu_{k f}\left[x_{i}\right]\right)$

dengan:

$\mu_{s f}\left[x_{i}\right]=$ nilai keanggotaan solusi fuzzy sampai aturan ke-I;

$\mu_{k f}\left[x_{i}\right]=$ nilai keanggotaan konsekuen fuzzy aturan ke-I;

4. Penegasan (Defuzzyfikasi)

Input dari proses Defuzzyfikasi adalah suatu himpunan fuzzy yang diperoleh dari komposisi aturan-aturan fuzzy, sedangkan output yang dihasilkan merupakan suatu bilangan pada domain himpunan fuzzy tersebut. Sehingga jika diberikan suatu himpunan fuzzy dalam range tertentu, maka harus dapat diambil suatu nilai crisp tertentu sebagai output [8].

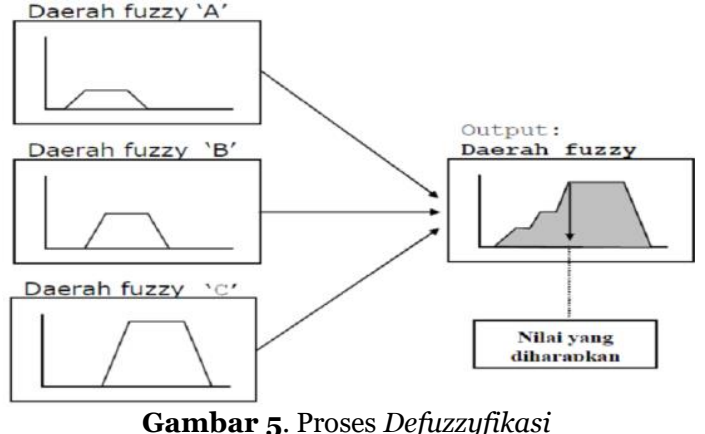

Gambar 5. Proses Defuzzyfikasi

Ada beberapa metode defuzzyfikasi pada komposisi aturan MAMDANI antara lain [8]:

1. Metode Centroid (Composite Moment). Pada metode centroid solusi crisp diperoleh dengan cara mengambil titik pusat daerah Fuzzy. Secara umum dapat dituliskan:

$$
\begin{aligned}
& Z^{*}=\frac{\int_{Z} z \mu(z) d z}{\int_{Z} \mu(z) d z} \rightarrow \text { untuk semesta kontinu } \\
& Z^{*}=\frac{\sum_{j=1}^{n} z_{j} \mu\left(z_{j}\right)}{\sum_{j=1}^{n} \mu\left(z_{j}\right)} \rightarrow \text { untuk semesta diskret } \\
& \text { Keterangan : } \\
& Z=\text { Nilai tegas }
\end{aligned}
$$

2. Metode Bisektor. Pada metode bisektor solusi crisp diperoleh dengan cara mengambil nilai pada domain yang memiliki nilai keanggotaan separuh dari jumlah total nilai keanggotaan pada daerah fuzzy.

Tabel 1. Contoh nilai keanggotaan fuzzy

$$
\begin{array}{ll}
\operatorname{Sum} \mu(z)=2,1 \\
\quad \operatorname{Sum} \mu(z) / 2=1,05
\end{array}
$$

Ambil nilai z dari yang hasil penjumlahan

$\mu(z) \geq 1,05$ Maka $\mathrm{z}=5000$

\begin{tabular}{|c|c|c|}
\hline Rule & $\mu(z)$ & $\mathrm{Z}$ \\
\hline 1 & 0,25 & 5750 \\
\hline 2 & 0,25 & 5750 \\
\hline 3 & 0,4 & 3000 \\
\hline 4 & 0,6 & 5000 \\
\hline 5 & 0,6 & 3000 \\
\hline
\end{tabular}

3. Metode Mean of Maximum (MOM). Pada metode mean of maximum solusi crisp diperoleh dengan cara mengambil nilai rata-rata domain yang memiliki nilai keanggotaan maksimum (tabel 1). Nilai MOM $=(5000+3000) / 2=4000$

4. Metode Largest of Maximum (LOM). Pada metode largest of maximum solusi crisp diperoleh dengan cara mengambil nilai terbesar dari domain yang memiliki nilai keanggotaan maksimum (tabel 1).

Nilai LOM $=5000$

5. Metode Smallest of Maximum (SOM). Pada metode smallest of maximum solusi crisp diperoleh dengan cara mengambil nilai terkecil dari domain yang memiliki nilai keanggotaan maksimum (tabel 1).

Nilai SOM $=3000$

\section{Sistem Pendukung Keputusan}

Sistem pendukung keputusan (SPK) adalah bagian dari sistem informasi berbasis komputer termasuk sistem berbasis pengetahuan atau manajemen pengetahuan yang dipakai untuk mendukung pengambilan keputusan dalam suatu organisasi atau perusahaan. Dapat juga dikatakan sebagai sistem komputer yang mengolah data menjadi 
informasi untuk mengambil keputusan dari masalah semi terstruktur yang spesifik [9].

\section{Uji-t Sampel Berpasangan}

Uji-t termasuk dalam golongan statistika parametrik. Statistik uji ini digunakan dalam pengujian hipotesis. Uji-t dapat dibagi menjadi 2, yaitu uji-t yang digunakan untuk pengujian hipotesis 1-sampel dan ujit yang digunakan untuk pengujian hipotesis 2-sampel. Bila dihubungkan dengan kebebasan (independency) sampel yang digunakan (khusus bagi uji-t dengan 2sampel), maka uji-t dibagi lagi menjadi 2, yaitu uji-t untuk sampel bebas (independent) dan uji-t untuk sampel berpasangan (paired) [10].

Uji t sampel berpasangan yaitu metode pengujian berdasarkan beda dua sampel yang berpasangan dan menentukan apakah hasilnya secara statistik berbeda. Uji t sampel dirumuskan sebagai berikut [10]:

Dimana :

$$
t=\frac{|| \bar{X}_{d}|-| X_{0}||}{\frac{S_{d}}{\sqrt{n}}}
$$

$\bar{X}_{d}=$ rata-rata selisih

$X_{0}=$ Nilai selisih yang diharapkan. Biasanya

bernilai o

$S_{d}=$ Standar deviasi dari selisih data

$\mathrm{n} \quad=$ Jumlah pasangan sampel

\section{METODOLOGI PENELITIAN}

\subsection{Waktu dan tempat Penelitian}

Penelitian ini dilakukan pada bulan Agustus 2017 sampai bulan Maret 2018 mulai dari penyusunan proposal penelitian, pengambilan data serta pengolahan data. Pengambilan data dilakukan di CV. Sinar Sukses Manado dan Pengolahan data dilakukan di Laboratorium Komputer Lanjut Jurusan Matematika FMIPA Universitas Sam Ratulangi.

\subsection{Metode Penelitian}

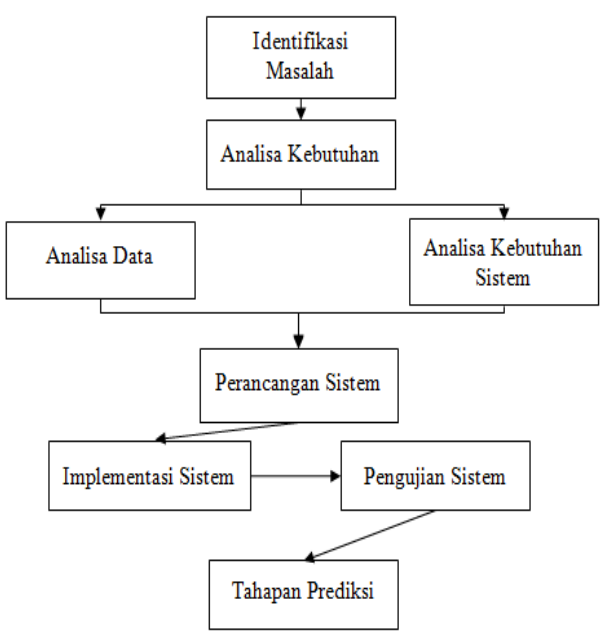

Gambar 6. Alur Metodologi Penelitian

\subsection{Perancangan Sistem}

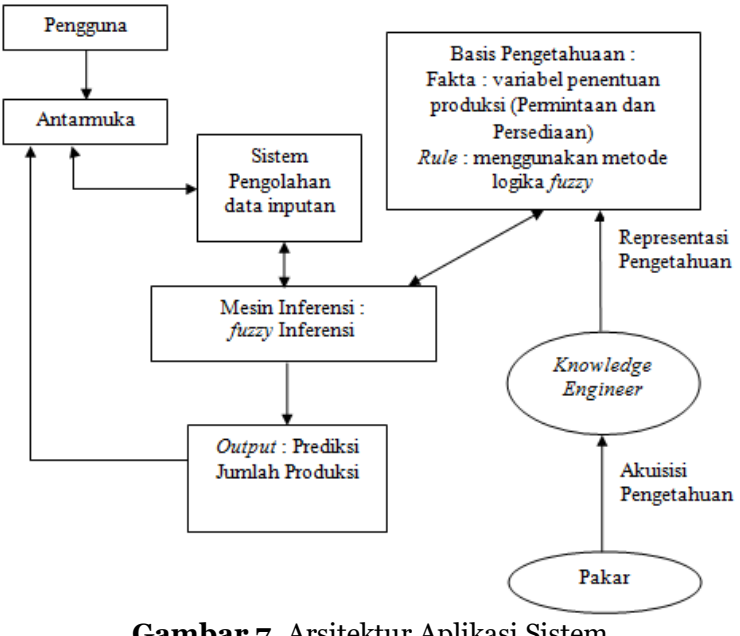

Gambar 7. Arsitektur Aplikasi Sistem

\subsection{Pengujian Sistem}

Pengujian sistem ini meliputi kinerja dari sistem aplikasi dalam melakukan prediksi jumlah produksi barang dan hasilnya akan dibandingkan dengan data hasil produksi perusahaan yang didapatkan dengan menggunakan uji statistik. Uji statistik yang digunakan pada penelitian ini merupakan uji-t dengan menggunakan software Minitab. Uji-t yang digunakan pada penelitian ini merupakan uji-t untuk sampel berpasangan (paired). Uji statistik ini bertujuan untuk melihat apakah hasil prediksi produksi dari sistem aplikasi yang dibuat lebih baik dari pada hasil produksi perusahaan sendiri.

Hipotesis yang akan digunakan pada pengujian statistik ini yaitu :

$H_{0}: \mu_{0}<\mu_{1}=$ Selisih antara produksi seharusnya dengan produksi perusahaan lebih kecil dari pada selisih produksi seharusnya dengan prediksi produksi menggunakan aplikasi.

$H_{1}: \mu_{0}>\mu_{1}=$ Selisih antara produksi seharusnya dengan produksi perusahaan lebih besar dari pada selisih produksi seharusnya dengan prediksi produksi menggunakan aplikasi.

dengan tingkat kepercayaan yaitu 95\% atau $\alpha=0,05$ dan kriteria pengujian yaitu: Jika P-value $>\alpha$ maka terima $\mathrm{H}_{\mathrm{o}}$, Jika P-value $<\alpha$ maka tolak $\mathrm{H}_{\mathrm{o}}$.

\subsection{Tahapan Prediksi}

Pada tahapan ini akan dilakukan prediksi jumlah produksi pintu dan lemari untuk bulan Desember 2017 berdasarkan data permintaan dan persediaan pada bulan tersebut dengan menggunakan sistem aplikasi yang akan dibangun.

\section{HASIL DAN PEMBAHASAN}

\subsection{Analisis Data}

Data yang diperoleh untuk digunakan dalam rancangan sistem yang dibuat adalah data per bulan dari jumlah permintaan, persediaan, dan produksi dari dua barang yaitu pintu dan lemari dari Januari 2013 sampai November 2017 dari perusahaan CV. Sinar Sukses Manado.

Dari data yang diperoleh, akan diolah menggunakan Fuzzy Inference System metode 
Mamdani untuk mendapatkan output dengan beberapa tahapan yaitu mendefinisikan variabel fuzzy, aplikasi fungsi implikasi, komposisi antar aturan dan defuzzyfikasi sebelum diimplementasikan ke dalam sistem pendukung keputusan.

\subsection{Mendefinisikan Variabel Fuzzy}

Dalam tahap ini, nilai keanggotaan himpunan permintaan dan persediaan akan dicari menggunakan fungsi keanggotaan himpunan fuzzy dengan memperhatikan nilai maksimum, nilai tengah dan nilai minimum data setiap variabel pada masing-masing barang. Variabel-variabel ini antara lain: variabel permintaan, variabel persediaan dan variabel produksi.

1. Variabel Permintaan

a. Fungsi permintaan pintu

$$
\begin{gathered}
\mu\left[x_{1}\right]_{\text {pmtrendah }}=\left\{\begin{array}{c}
1 ; x \leq 30 \\
\frac{1}{17}(47-x) ; 30<x<47 \\
0 ; x \geq 47
\end{array}\right. \\
\mu\left[x_{1}\right]_{\text {pmtsedang }}=\left\{\begin{array}{c}
0 ; x_{1} \leq 30 \\
\frac{1}{17}\left(x_{1}-30\right) ; 30<x_{1}<47 \\
1 ; x_{1}=47
\end{array}\right. \\
\mu\left[x_{1}\right]_{\text {pmttinggi }}=\left\{\begin{array}{c}
\frac{1}{18}\left(65-x_{1}\right) ; 47<x_{1}<65 \\
0 ; x_{1} \geq 65 \\
0 ; x_{1} \leq 48 \\
\frac{1}{18}\left(x_{1}-47\right) ; 47<x_{1}<65 \\
1 ; x_{1} \geq 65
\end{array}\right.
\end{gathered}
$$

b. Fungsi permintaaan lemari

$$
\begin{aligned}
& \mu\left[x_{2}\right]_{\text {pmtrendah }}=\left\{\begin{array}{c}
1 ; x_{2} \leq 20 \\
\frac{1}{6}\left(26-x_{2}\right) ; 20<x_{2}<26 \\
0 ; x_{2} \geq 26
\end{array}\right. \\
& \mu\left[x_{2}\right]_{\text {pmtsedang }}=\left\{\begin{array}{c}
0 ; x_{2} \leq 20 \\
\frac{1}{6}\left(x_{2}-20\right) ; 20<x_{2}<26 \\
1 ; x_{2}=26 \\
\frac{1}{6}\left(32-x_{2}\right) ; 26<x_{2}<32 \\
0 ; x_{2} \geq 32
\end{array}\right. \\
& \mu\left[x_{2}\right]_{\text {pmtting } i}=\left\{\begin{array}{c}
0 ; x_{2} \leq 26 \\
\frac{1}{6}\left(x_{2}-26\right) ; 26<x_{2}<32 \\
1 ; x_{2} \geq 32
\end{array}\right.
\end{aligned}
$$

2. Variabel Persediaan

a. Fungsi persediaan pintu

$$
\begin{gathered}
\mu\left[x_{1}\right]_{\text {psdsedikit }}=\left\{\begin{array}{c}
1 ; x_{1} \leq 9 \\
\frac{1}{5}\left(14-x_{1}\right) ; 9<x_{1}<14 \\
0 ; x_{1} \geq 14
\end{array}\right. \\
\mu\left[x_{1}\right]_{p s d s e d a n g}=\left\{\begin{array}{c}
\frac{1}{5}\left(x_{1}-9\right) ; 9<x_{1}<14 \\
1 ; x_{1}=14 \\
\frac{1}{6}\left(20-x_{1}\right) ; 14<x_{1}<20 \\
0 ; x_{1} \geq 20
\end{array}\right.
\end{gathered}
$$

$$
\mu\left[x_{1}\right]_{\text {psdbanyak }}=\left\{\begin{array}{c}
0 ; x_{1} \leq 14 \\
\frac{1}{6}\left(x_{1}-14\right) ; 14<x_{1}<20 \\
1 ; x_{1} \geq 20
\end{array}\right.
$$

b. Fungsi persediaan lemari

$$
\begin{gathered}
\mu\left[x_{2}\right]_{\text {psdsedikit }}=\left\{\begin{array}{c}
1 ; x_{2} \leq 6 \\
\frac{1}{6}\left(12-x_{2}\right) ; 6<x_{2}<12 \\
0 ; x \geq 12
\end{array}\right. \\
\mu\left[x_{2}\right]_{\text {psdsedang }}=\left\{\begin{array}{c}
0 ; x_{2} \leq 6 \\
\frac{1}{6}\left(x_{2}-6\right) ; 6<x_{2}<12 \\
1 ; x_{2}=12
\end{array}\right. \\
\mu\left[x_{2}\right]_{\text {psdbanyak }}=\left\{\begin{array}{r}
\frac{1}{6}\left(18-x_{2}\right) ; 12<x_{2}<18 \\
0 ; x_{2} \geq 18 \\
\frac{1}{6}\left(x_{2}-12\right) ; 12<x_{2} \leq 12 \\
1 ; x_{2} \geq 18
\end{array}\right.
\end{gathered}
$$

3. Variabel Produksi

a. Fungsi produksi pintu

$$
\begin{gathered}
\mu\left[x_{1}\right]_{\text {prdberkurang }}=\left\{\begin{array}{c}
1 ; x_{1} \leq 35 \\
\frac{1}{15}\left(50-x_{1}\right) ; 35<x_{1}<50 \\
0 ; x_{1} \geq 50
\end{array}\right. \\
\mu\left[x_{1}\right]_{\text {prdtetap }}=\left\{\begin{array}{c}
0 ; x_{1} \leq 35 \\
\frac{1}{15}\left(x_{1}-35\right) ; 35<x_{1}<50 \\
1 ; x_{1}=50
\end{array}\right. \\
\mu\left[x_{1}\right]_{\text {prdbertambah }}=\left\{\begin{array}{c}
\frac{1}{15}\left(65-x_{1}\right) ; 50<x_{1}<65 \\
0 ; x_{1} \geq 65 \\
0 ; x_{1} \leq 50
\end{array}\right. \\
\frac{1}{15}\left(x_{1}-50\right) ; 50<x_{1}<65 \\
1 ; x_{1} \geq 65
\end{gathered}
$$

b. Fungsi Produksi lemari

$$
\begin{gathered}
\mu\left[x_{2}\right]_{\text {prdberkurang }}=\left\{\begin{array}{c}
1 ; x_{2} \leq 20 \\
\frac{1}{10}\left(30-x_{2}\right) ; 20<x_{2}<30 \\
0 ; x_{2} \geq 30
\end{array}\right. \\
\mu\left[x_{2}\right]_{\text {prdtetap }}=\left\{\begin{array}{c}
\frac{1}{10}\left(x_{2}-20\right) ; 20<x_{2}<20 \\
1 ; x_{2}=30 \\
\frac{1}{10}\left(40-x_{2}\right) ; 30<x_{2}<40 \\
0 ; x_{2} \geq 40
\end{array}\right. \\
\mu\left[x_{2}\right]_{\text {prdbertambah }}=\left\{\begin{array}{c}
0 ; x_{2} \leq 30 \\
\frac{1}{10}\left(x_{2}-30\right) ; 30<x_{2}<40 \\
1 ; x_{2} \geq 40
\end{array}\right.
\end{gathered}
$$

Dengan mengkombinasikan himpunan-himpunan dari setiap variabel fuzzy tersebut, maka diperoleh sembilan aturan fuzzy sebagai berikut: 
[R1] IF Permintaan RENDAH And Persediaan BANYAK THEN Produksi Barang BERKURANG;

[R2] IF Permintaan RENDAH And Persediaan SEDANG THEN Produksi Barang BERKURANG;

[R3] IF Permintaan RENDAH And Persediaan SEDIKIT THEN Produksi Barang BERKURANG;

[R4] IF Permintaan SEDANG And Persediaan BANYAK THEN Produksi Barang BERKURANG;

[R5] IF Permintaaan SEDANG And Persediaan SEDANG THEN Produksi Barang TETAP;

[R6] IF Permintaan SEDANG And Persediaan SEDIKIT THEN Produksi Barang BERTAMBAH;

[R7] IF Permintaan TINGGI And Persediaan BANYAK THEN Produksi Barang BERTAMBAH;

[R8] IF Permintaan TINGGI And Persediaan SEDANG THEN Produksi Barang BERTAMBAH;

[R9] IF Permintaan TINGGI And Persediaan SEDIKIT THEN Produksi Barang BERTAMBAH.

\subsection{Aplikasi Fungsi Implikasi}

Sebelum masuk pada tahapan ini, akan dipilih 1 data yang akan diprediksi untuk menunjukkan contoh perhitungan secara manual. Contoh data yang akan dihitung manual adalah data pintu pada bulan Januari 2013 yaitu permintaan 32 unit dan persediaan 10 unit.

Tahap 1. Hitung Nilai Keanggotaan himpunan dari setiap variabel menggunakan fungsi yang sudah di bentuk.

Permintaan 32 unit (karena 32 masuk dalam fungsi keanggotaan permintaan rendah dan sedang berdasarkan grafik pada gambar 9 dan 10, maka gunakan fungsi keanggotaan permintaan rendah dan sedang).

$\mu\left[x_{1}\right]_{\text {pmtrendah }}=\frac{47-32}{47-30}=\frac{15}{17}=0,882353$

$\mu\left[x_{1}\right]_{\text {pmtsedang }}=\frac{32-30}{47-30}=\frac{2}{17}=0,117647$

Persediaan 10 unit (karena 10 masuk dalam fungsi keanggotaan persediaan sedikit dan sedang berdasarkan grafik pada gambar 15 dan 16, maka gunakan fungsi keanggotaan persediaan sedikit dan sedang).

$\mu\left[x_{1}\right]_{\text {psdsedikit }}=\frac{14-10}{14-9}=\frac{4}{5}=0,8$

$\mu\left[x_{1}\right]_{\text {psdsedang }}=\frac{10-9}{14-9}=\frac{1}{5}=0,2$

Tahap 2. Inferensi aturan yang telah dibentuk.

Karena yang digunakan dalam variabel permintaan (RENDAH, SEDANG) dan persediaan (SEDIKIT, SEDANG) maka hanya berlaku 4 aturan yaitu :

[R2] IF Permintaan RENDAH And Persediaan SEDANG THEN Produksi BERKURANG

$$
\begin{aligned}
\alpha_{2} & =\mu\left[x_{1}\right]_{\text {pmtrendah }} \cap \mu\left[x_{1}\right]_{\text {psdsedang }} \\
& =\min (0,882,0,2) \\
& =0,2
\end{aligned}
$$

[R3] IF Permintaan RENDAH And Persediaan SEDIKIT THEN Produksi BERKURANG

$$
\begin{aligned}
\alpha_{3} & =\mu\left[x_{1}\right]_{\text {pmtrendah }} \cap \mu\left[x_{1}\right]_{\text {psdsedikit }} \\
& =\min (0,882,0,8) \\
& =0,8
\end{aligned}
$$

[R5] IF Permintaan SEDANG And Persediaan SEDANG THEN Produksi TETAP

$$
\begin{aligned}
\alpha_{5} & =\mu\left[x_{1}\right]_{\text {pmtsedang }} \cap \mu\left[x_{1}\right]_{\text {psdsedang }} \\
& =\min (0,117647,0,2) \\
& =0,117647
\end{aligned}
$$

[R6] IF Permintaan SEDANG And Persediaan SEDIKIT THEN Produksi BERTAMBAH

$$
\begin{aligned}
\alpha_{6} & =\mu\left[x_{1}\right]_{\text {pmtsedang }} \cap \mu\left[x_{1}\right]_{\text {psdsedikit }} \\
& =\min (0,89,0,2) \\
& =0,117647
\end{aligned}
$$

\subsection{Komposisi Setiap Aturan}

Dari hasil inferensi tiap aturan digunakan, digunakan metode max untuk melakukan komposisi antar semua aturan.

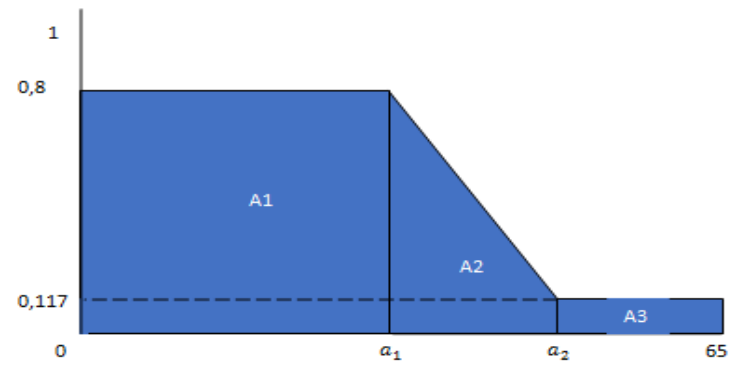

Gambar 8. Kurva komposisi aturan fuzzy

Cari nilai $a_{1}$ dan $a_{2}$ berdasarkan grafik pada gambar 8 .

$$
\begin{aligned}
& \text { - } \frac{50-a_{1}}{50-35}=0,8 \\
& 50-a_{1}=0,8(15) \\
& a_{1}=38 \\
& \text { - } \frac{50-a_{2}}{50-35}=0,117647 \\
& 50-a_{2}=0,117647 \text { (15) } \\
& a_{2}=48,2353
\end{aligned}
$$

Dengan demikian, fungsi keanggotaan untuk hasil komposisi ini adalah:

$$
\mu[z]=\left\{\begin{array}{cc}
0,8 ; z \leq 38 \\
\frac{50-z}{50-35} \quad ; 38<z<48,2353 \\
0,117647 \quad ; z \geq 48,2353
\end{array}\right.
$$

\subsection{Defuzzyfikasi}

Metode yang akan digunakan adalah metode centroid, untuk itu pertama-tama dihitung dulu momen untuk setiap daerah kurva komposisi aturan pada gambar 8 .

$$
\begin{gathered}
M 1=\int_{0}^{38} 0,8 z d z=0,\left.4 z^{2}\right|_{0} ^{38}=577,6 \\
M 2=\int_{38}^{48,2353} \frac{50-z}{50-35} z d z=\frac{1}{15} \int_{38}^{48,2353}\left(50 z-z^{2}\right) d z \\
=\frac{1}{15}\left[25 z^{2}-\frac{1}{3} z^{3}\right]_{38}^{48,2353} \\
M 3=\int_{48,2353}^{65} 0,117647 z d z=0,\left.058824 z^{2}\right|_{48,245} ^{65} \\
=111,668
\end{gathered}
$$

Hitung luas setiap daerah kurva pada gambar 19.

$$
\begin{gathered}
A 1=38 \times 0,8=30,4 \\
A 2=\frac{(0,117647+0,8)(48,2353-38)}{2}=4,696194 \\
A 3=(65-48,2353) \times 0.117647=1,972317
\end{gathered}
$$

Terakhir gunakan metode centroid untuk mendapatkan nilai tegasnya 


$$
z=\frac{577,6+196,5318+111,668}{30,4+4,696194+1,972317}=23,89629=24
$$

Maka banyaknya pintu yang harus diproduksi oleh perusahaan pada bulan Januari 2013 adalah sebanyak 24 unit. Jumlah ini akan diuji pada sistem pendukung keputusan yang akan dibuat apakah sesuai atau tidak dengan hitungan manual.

\subsection{Implementasi Sistem Pendukung \\ Keputusan}

Pada tahapan implementasi sistem, program dibagi ke dalam 2 komponen utama yaitu beranda dan proses prediksi. Pada tahap ini juga akan dilakukan pengujian terhadap program untuk melihat apakah program berjalan dengan baik atau tidak.

\subsubsection{Jendela Beranda}

Jendela beranda adalah tampilan awal dari program saat program ini mulai di running. Tampilan awalnya berupa gambar dan nama dari perusahaan CV. Sinar Sukses dan terdapat 2 push button yang langsung mengalihkan program dari tampilan awal ke tampilan proses prediksi seperti pada gambar 9. Dengan penjelasan masing-masing push button pada jendela beranda adalah seperti terlihat pada tabel 2 .

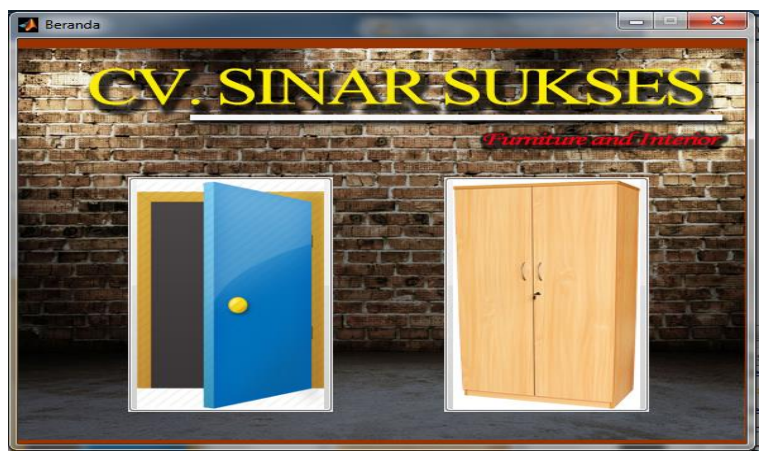

Gambar 9. Tampilan jendela beranda

Tabel 2. Penjelasan jendela beranda

\begin{tabular}{|c|l|}
\hline Push Button & \multicolumn{1}{|c|}{ Penjelasan dan Fungsi } \\
\hline Icon Pintu & $\begin{array}{l}\text { Tempat untuk melakukan prediksi } \\
\text { produksi pada pintu seperti } \\
\text { terlihat pada gambar 23. }\end{array}$ \\
\hline Icon Lemari & $\begin{array}{l}\text { Tempat untuk melakukan prediksi } \\
\text { produksi pada lemari seperti } \\
\text { terlihat pada gambar 24. }\end{array}$ \\
\hline
\end{tabular}

\subsubsection{Jendela Proses}

Jendela proses merupakan bagian paling utama dari program dimana pada jendela ini akan mulai dilakukan prediksi produksi terhadap dua barang. Tampilan jendela proses untuk kedua barang tersebut seperti pada gambar 10 dan 11. Pada masingmasing jendela proses terdapat tool bar yang sama yang terletak dibawah tittle bar pintu dan lemari dengan 1 push button prediksi untuk melihat hasil prediksi. Penjelasan tentang tool bar seperti pada tabel

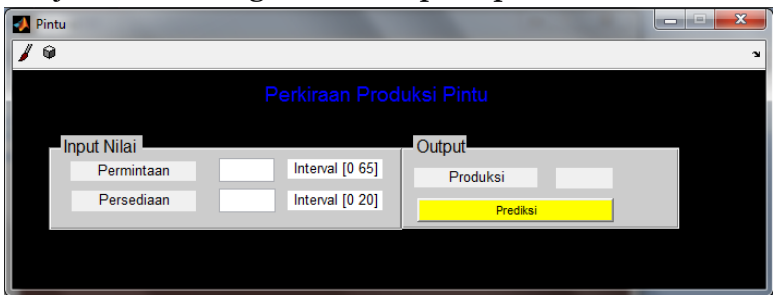

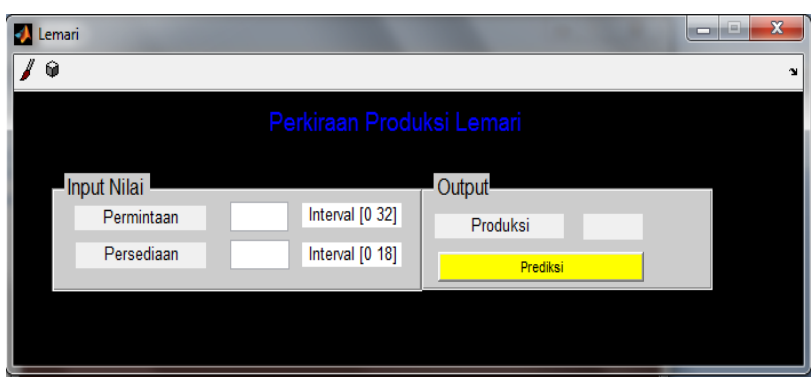

Gambar 11. Tampilan jendela proses untuk lemari

Tabel 3. Penjelasan toolbar proses.

\begin{tabular}{|l|l|}
\hline Tool Bar & \multicolumn{1}{|c|}{ Penjelasan dan fungsi } \\
\hline & $\begin{array}{l}\text { Berfungsi untuk menghapus semua } \\
\text { proses prediksi dan mengembalikan } \\
\text { tampilan seperti semula. }\end{array}$ \\
\hline
\end{tabular}

\subsection{Pengujian Sistem}

Pada tahapan pengujian, akan di jelaskan secara berurutan cara kerja sistem pendukung keputusan untuk melakukan prediksi produksi dengan fuzzy inference system mamdani. Tahap awal jalankan program lalu akan langsung masuk pada tampilan jendela beranda dan pilih salah satu barang yang akan diproduksi, misalnya pintu dengan menekan push button dengan icon pintu.

Setelah masuk pada jendela pintu, selanjutnya uji data produksi pintu bulan januari 2013 dari perusahaan CV. Sinar Sukses dengan memasukkan jumlah permintaan 32 unit dan persediaan 10 unit dan klik tombol prediksi seperti pada gambar 12 .

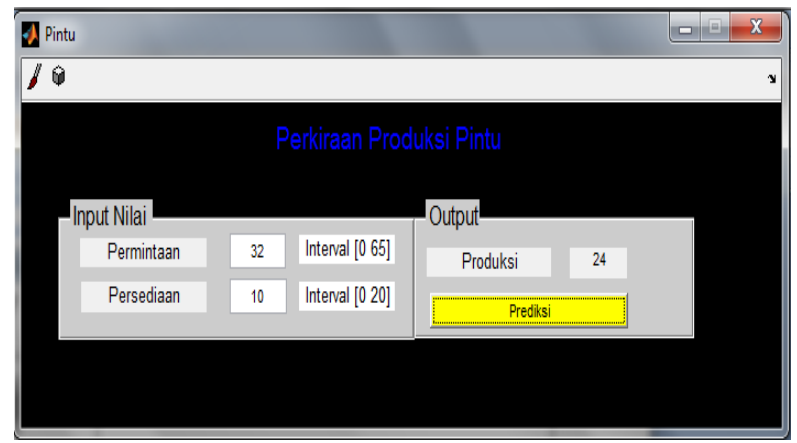

Gambar 12. Prediksi produksi pintu bulan Januari 2013

Setelah diuji, didapatkan hasil pada sistem pendukung keputusan untuk produksi pintu pada bulan Januari 2013 yaitu sebanyak 24 unit yang harus diproduksi. Hasil prediksi aplikasi ini sama seperti hitungan manual sebelumnya yang artinya program ini berjalan sesuai dengan apa yang diharapkan dan dilanjutkan ke prediksi seluruh data.

Selanjutnya dari hasil prediksi keseluruhan dat akan dilakukan perhitungan untuk mencari selisih antara produksi seharusnya dengan produksi perusahaan dan selisih produksi seharusnya dengan prediksi produksi untuk diuji menggunakan uji statistik pada software statistika untuk melihat tingkat keakuratan sampel yang diambil.

Gambar 10. Tampilan jendela proses untuk pintu 
[5] Rindengan A.J., P.T. Supriyo, dan A. Kustiyo. 2013. Model Fuzzy Goal Programming Yang Diselesaikan Dengan Linear Programming Pada Perencanaan Produksi. Jurnal de Cartesian. 2(2):26-32.

[6] Assauri, S. 1993. Manajemen Produksi dan Operasi. Fakultas Ekonomi Universitas Indonesia, Jakarta.

[7] Chen, G. Pham, and T. Tat. 2000. Introduction to Fuzzy Sets, Fuzzy Logic, and Fuzzy Control System. CRC Press, London.

[8] Kusumadewi, S. 2010. Aplikasi Logika Fuzzy untuk Pendukung Keputusan. Graha Ilmu, Yogyakarta.

[9] Zarkasi, A., N. Widyastuti., dan E. Kumalasari. 2015. Penerapan Sistem Pendukung Keputusan Metode Fuzzy Tsukamoto Dalam Pengoptimalan Produksi Barang Berdasarkan Data Persediaan Dan Jumlah Permintaan Di Loverandliars Cloth. Jurnal Script. 3(1) : 1-10.

[10] Suryono, H., dan T. Rejekiningsih. 2007. Uji Persyaratan Analisis Statistik. Inovasi Pendidikan. 8(2): 187-196.

Try Buana Donda (tryandonda@gmail.com) lahir dan

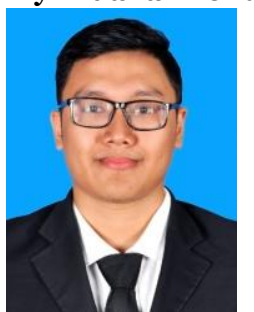
tinggal di Modayag, Kecamatan Modayag, Boltim. Dia masih menempuh pendidikan tinggi Program Studi Matematika dan Ilmu Pengetahuan Alam Universitas Sam Ratulangi Manado. Tahun 2018 adalah tahun terakhir ia menempuh studi. Makalah in merupakan hasil penelitian skripsinya yang di publikasikan.

Chriestie E.J.C Montolalu (chriestelly@yahoo.com) Pada tahun 2007, gelar Sarjana Sains (S.Si) diperoleh dari Universitas Sam Ratulangi Manado. Gelar Master of Science (M.Sc) diperoleh dari Universitas of Queensland Australia pada tahun 2015. Ia bekerja di UNSRAT di Program Studi Matematika UNSRAT sebagai pengajar akademik (Dosen) mulai dari tahun 2008 sampai sekarang.

Altien J. Rindengan (altien@unsrat.ac.id)

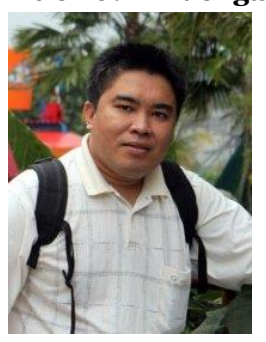

Pada tahun 1999, memperoleh gelar sarjana di Departemen Matematika, Fakultas Matematika dan Ilmu Pengetahuan Alam, Institut Pertanian Bogor. Gelar magister ilmu komputer diperoleh dari Departemen Ilmu Komputer, Institut Pertanian Bogor pada tahun 2012. Menjadi dosen di Departemen Matematika, Fakultas Matematika dan Ilmu Pengetahuan Alam, Universitas Sam Ratulangi Manado sejak tahun 2001 sampai sekarang. Fokus penelitianpenelitian yang dilakukan adalah riset operasi, sistem pendukung keputusan, sistem fuzzy dan image proceesing. 